\title{
Popular Publics: Street Protest and Plaza Preachers in Caracas*
}

\author{
DAVID SMILDE
}

Summary: Classic liberal conceptions of the public sphere generally miscast the public participation of popular sectors in the developing world as premodern, proto-political, or nonrational. The term "popular intellectual" is a useful corrective since it focuses attention on discourses and symbols that are consciously created and endure beyond the individuals and events which put them into play. The term "popular publics" - intentionally organized relational contexts in which specific networks of people from the popular classes seek to bridge to other networks, form coalitions, and expand the influence of their discourse - preserves this emphasis but also changes the unit of analysis from individual or collective actors to relational contexts. Here I use this concept to analyze two cases of popular public participation in late twentieth-century Caracas, Venezuela. In the first case we will look at a street protest, in which dislocated members of the informal economy work to make their private concerns into public issues. In the second case, we will look at plaza services, in which Pentecostal Christians address Venezuela's contemporary social and political reality through an alternative rationality. Each of these cases challenge classic liberal concepts of the public sphere.

FROM POPULAR INTELLECTUALS TO POPULAR PUBLICS

The term "popular intellectuals" contains an interesting tension. On the one hand, "intellectuals" refers to people with a special vocation in reflecting upon and discussing issues of collective social life. In both critical and approbatory uses it generally refers to elites who are relatively insulated from the vicissitudes of concrete, everyday life. "Popular", on the

* This article benefited from presentations at the Culture and Institutions Workshop at the University of Georgia, the 2004 Annual Meetings of the Eastern Sociological Society, as well as comments by, or discussion with, Janise Hurtig, George Philip, Patricia Richards, and Alejandro Velasco. The research on Pentecostals was supported by a US Department of Education Fulbright-Hays fellowship. The research on protest was supported by grants from the Consejo Latinoamericano de Ciencias Sociales, Buenos Aires, and the Consejo Nacional de Ciencia y Tecnología of Venezuela. Previous analyses of the informal workers' street protest appeared in David Smilde, "Protagonismo Cultural desde la Pobreza: Respuesta a Mikel de Viana", Revista Venezolana de Economía y Ciencias Sociales, 7 (200I), pp. 45-64; and, Margarita López Maya et al., Protesta y Cultura en Venezuela: Los Marcos de Acción Colectiva en 1999 (Caracas, 2002). 
other hand, is generally used by intellectuals precisely to refer to non-elites who are organically grounded in concrete, everyday life. As Raymond

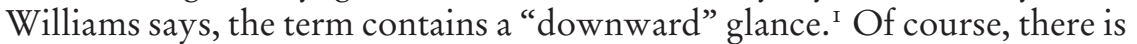
frequently a small but important overlap between popular and intellectual classes. Thus, Max Weber's prophets were usually marginal men who came to have far-reaching significance for social change. ${ }^{2}$ Nevertheless, an exclusive focus on discrete individuals who function as intellectuals can lead us to pass over other forms of popular intellectualism that make important contributions to discussion of collective social life in the developing world. In this article, I will focus on events and contexts in which flexible, occasional social actors disseminate alternative discourses in Caracas, Venezuela.

Classic liberal conceptions of the public sphere generally do not cast a favorable light on popular participation in developing regions of the world. In Jurgen Habermas's account, ${ }^{3}$ a public sphere is a social space controlled neither by the state nor the economy, in which private citizens set aside their personal interests in order to deliberate on issues of common interest in terms of rational-critical debate. From this perspective, popular participation in places like Caracas generally looks deformed, premodern or protopolitical, insofar as it directly brings in issues of personal wellbeing and/or communicates in idioms other than those of rational-critical debate. Of course, the liberal conception of the public sphere has received ample criticism, both theoretical and historical. ${ }^{4}$ Nancy Fraser, 5 for example, argues that, historically, whether an issue is of private or public concern, and what counts as "rational" have themselves been contentious issues disputed in public. Furthermore, she argues that a unitary conceptualization of the public sphere marginalizes non-dominant sectors of society.

Recent work among sociologists has attempted to unpack the concept of "public" and make it more versatile and sensitive to multiplicity. This work is inspired by the trend towards conceptualizing social networks as discourses that connect actors. " ${ }^{6}$ "Publics", then, are relational contexts in which normally segmented social networks and their associated discourses come into contact in open-ended ways. ${ }^{7}$ As such, publics are sites in which

I. Raymond Williams, Keywords: A Vocabulary of Culture and Society, rev. edn (New York, I983).

2. Max Weber, The Sociology of Religion, Ephraim Fischoff (tr.) (Boston, MA, I963 [1922]).

3. Jurgen Habermas, The Structural Transformation of the Public Sphere, Thomas Berger (tr.) (Cambridge, 1989 [1962]).

4. For a good collection of critical treatments see Craig Calhoun (ed.), Habermas and the Public Sphere (Cambridge, 1992).

5. Nancy Fraser, "Rethinking the Public Sphere", in Calhoun, Habermas and the Public Sphere, pp. I09-142.

6. The seminal contribution in this trend is Harrison White, Identity and Control: A Structural Theory of Action (Princeton, NJ, I992).

7. Mustafa Emirbayer et al., "Publics in History", Theory and Society, 28 (1999), pp. I45-197; 
distinct networks are bridged, new understandings develop, and coalitions are formed. Rather than an absence of structure, publics usually exhibit stable features, involve existing social networks and discourses, and are shot through with power dynamics. ${ }^{8}$ Thus, they are not liminal "free spaces" but structured relational contexts in which new articulations of structure can occur. ${ }^{9}$ Publics can also be the objects of agency. ${ }^{10}$ While their power comes from their open-endedness and resulting unpredictability, they are often planned by actors precisely to extend their networks and associated discourses.

I will refer to the cases I examine here as "popular publics". ${ }^{\text {I }}$ In each case, we will see an intentionally organized relational context in which a specific network of people from the popular classes seeks to bridge to other networks, form coalitions, and expand the influence of its discourse. The cases will provide opportunities to explore the limits of the liberal concept of the public sphere as pointed out by Fraser. In the first case, we will see how marginalized social actors - in this case members of the informal economy - attempt to make their "private" concerns public through street protest. In the second case, we will see Pentecostals address Venezuela's contemporary social and political reality in plaza services, using a logic other than that of rational-critical debate. Before moving to the case material I would like to briefly review relevant aspects of the Venezuelan context.

\section{CONTEXT: VENEZUELA AT THE END OF THE TWENTIETH CENTURY}

Few national contexts in recent history have seen more mobilized public discussion than Venezuela. But while the current political conflict over the

Eiko Ikegami, "A Sociological Theory of Publics: Identity and Culture as Emergent Properties in Networks", Social Research, 67 (2000), pp. 989-1029; Ann Mishe et al., "Composing a Civic Arena: Publics, Projects, and Social Settings”, Poetics, 27 (2000), pp. 163-194.

8. Francesca Polletta, “Free Spaces' in Collective Action”, Theory and Society, 28 (1999), pp. $\mathrm{I}-38$; Emirbayer, "Publics in History".

9. Javier Auyero, "Relational Riot: Austerity and Corruption Protest in the Neoliberal Era", Social Movement Studies, 2 (2003), pp. I I7-I45.

Io. Ikegami, "A Sociological Theory of Publics"; Taeku Lee, Mobilizing Public Opinion: Black Insurgency and Racial Attitudes in the Civil Rights Era (Chicago, IL, 2002); Ann Mische, "Cross-talk in Social Movements: Reconceiving the Culture-Network Link", in Mario Diani et al. (eds), Social Movements and Networks: Relational Approaches to Collective Action (Oxford, 2003).

I I. I find this more open-ended than Nancy Fraser's term "subaltern counter-publics"; Fraser, "Rethinking the Public Sphere". "Subaltern" prioritizes the dominant/dominated binary as the most relevant social characteristic of the public being studied, and "counter" prioritizes resistance in the discourse and action carried out. This easily leads researchers to pass over other salient social characteristics of a public as well as the emic terms of its discourse. 
presidency of Hugo Chávez Frias has generated much debate, most positions have actively distorted understanding of Venezuelan democracy. Politicized analyses portray Venezuela's I958-I 998 democracy either as a stable and well-functioning regime that is abruptly being pushed into instability and conflict by Chávez, ${ }^{12}$ or as a corrupt, forty-year farce that is being heroically revolutionized by him. ${ }^{13}$ Both tendencies are wildly offbase. Chávez's ascendancy to power, as well as the political conflict it has generated, should be seen instead as the most recent stages in a remarkable process of economic and political development that has facilitated the rise of a healthy, literate, organized, and media-soaked population that can no longer be contained by corporatist political structures. Limitations of space keep me from documenting the shortcomings and achievements of Venezuela's 1958-1998 democracy - a history that is readily available elsewhere. ${ }^{14}$ Here I will simply review the emergence of challenges to its corporatist structures.

From the mid I980s, Venezuela has been a microcosm of the neoliberal restructuring taking place throughout the region. ${ }^{\mathrm{IS}}$ The decline of its import-substitution industries diminished the size and strength of the blue-collar industrial working class while the ranks of the urban informal economy swelled. The two parties that long dominated Venezuelan politics at every level were completely incapable of containing the demands of a highly urban population that was increasingly diverse and increasingly connected to the mass media. ${ }^{16}$ Attempts at change within these parties were usually met with expulsions or divisions, which created a context of party infighting and stagnation. ${ }^{17}$ The growth of social movements and civil associations, in contrast, meant that discussions of

I2. Moises Naim, "Hugo Chávez and the Limits of Democracy", New York Times, 5 March 2003; www.nytimes.com.

I3. Michael Derham, "Undemocratic Democracy: Venezuela and the Distorting of History", Bulletin of Latin American Research, 2I (2002), pp. 270-289.

I4. Daniel H Levine, "The Decline and Fall of Democracy in Venezuela: Ten Theses”, Bulletin of Latin American Research, 2 I (2002), pp. 248-269; Brian F. Crisp, Democratic Institutional Design: The Powers and Incentives of Venezuelan Politicians and Interest Groups (Stanford, CA, 2000).

I 5. Alejandro Portes et al., "Latin American Class Structures: Their Composition and Change during the Neoliberal Era", Latin American Research Review, 38 (2003), pp. 4I-82; Kenneth Roberts, "Social Inequalities without Class Cleavages in Latin America's Neoliberal Era", Studies in Comparative International Development, 36 (2002), pp. 3-33; Kenneth Roberts, "Social Polarization and the Populist Resurgence in Venezuela", in Venezuelan Politics in the Chávez Era: Class, Polarization and Conflict (Boulder, CO, 2003).

I6. Brian F. Crisp, Daniel H. Levine, and Juan Carlos Rey, "The Legitimacy Problem", in Jennifer McCoy et al. (eds), Venezuelan Democracy Under Stress (New Brunswick, NJ, 1995), pp. I39-170; Edgardo Lander, Neoliberalismo, Sociedad Civil y Democracia. Ensayos sobre America Latina y Venezuela (Caracas, I995); Levine, "Democracy in Venezuela".

17. Levine, "Democracy in Venezuela"; Roberts, "Social Polarization and Populist Resurgence in Venezuela". 
collective life were increasingly carried out by movements that did not justify themselves in terms of "the programmatic political rationality that was traditionally offered to the country as the path to construction of a modern society". ${ }^{18}$

There were also more direct assaults on the status quo. February 1989 saw three days of looting and rioting that resulted in hundreds of deaths and billions of dollars of damage. This was the beginning of a wave of protest that lasted throughout the $1990{ }^{19}{ }^{19}$ I 992 saw two coup attempts against President Carlos Andrés Pérez, who was subsequently impeached. I 993 saw the first election of a presidential candidate not affiliated with either major party. And by 1998, none of the leading candidates in the presidential elections identified with the traditional political parties. The eventual winner, of course, was Chávez, running on an antiparty, anticorruption platform and promising to radically change the country through a new constitution.

For the purposes of this paper, the relevant point is that Venezuelan democracy is suffering not only from its defects but also from its success. The progressive growth of the critically engaged civil society it engendered has in turn fueled challenges to its institutional context. ${ }^{20}$ In the following, we will see two manifestations of that public ferment at the end of Venezuela's twentieth century.

\section{STREET PROTEST: THE REINVASION OF LA HOYADA MARKET}

The February 1989 riots initiated a cycle of protest in Venezuela that lasted throughout the I990s. Provea, a Venezuelan human rights organization, recorded over 7,000 protests reported in the Venezuelan media during the I990s, amounting to more than two a day. ${ }^{2 \mathrm{I}}$ Were smaller protests that did not receive media attention included, this number would likely double. Peaks in protest activity were recorded in 1993 and 1994, during the impeachment of President Andrés Pérez and the banking crisis of the first

I8. Gabriela Uribe and Edgardo Lander, "Acción Social, Efectividad Simbólica y Nuevos Ambitos de lo Político", in Lander, Neoliberalismo, Sociedad Civil y Democracia.

19. Margarita Lopez Maya, "La Protesta Popular Venezolana entre I989 y I993 (en el umbral del neoliberalismo)", in Margarita Lopez Maya (ed.), Lucha Popular, Democracia, Neoliberalismo: Protesta Popular en America Latina en los Años de Ajuste (Caracas, 1999).

20. Ironically, the current conflict in Venezuela is a product of the same process insofar as the Chávez government can be seen as a nationalist attempt to re-establish the structures of corporatist democracy. His centralization of state power, revolutionary rhetoric, and actual or symbolic alliances with totalitarian figures such as Marcos Pérez Jimenez, Fidel Castro, and Mao Tse Tung, have led elements of organized civil society to counter-mobilize with devastating results, including an attempted coup in April 2002, a \$9-billion general strike eight months later, and continual protests in the streets.

2 I. López Maya et al., Protesta y Cultura en Venezuela. 
year of President Rafael Caldera's presidency, as well as I999, the first year of the Chávez administration. Often stereotyped as unplanned, emotional "free-market protests" similar to the bread riots of early capitalism, ${ }^{22}$ actual participant observation provides a quite different image. As will be seen below, protest events are better seen as popular publics in which citizens marginalized by institutionalized democratic channels attempt to create a relational context in which they can put forth their vision of the issues that affect them, as well as publicly define themselves. In any protest, journalists, public officials, sympathizers, or passers-by stop to talk with or watch the protesters. Protestors, in turn, use these interactions to express a vision of their struggle, of the society, and of themselves. Since understanding any given protest event requires an understanding of the concrete struggle of which it is a manifestation, here I will look at just one event carried out by a group of informal micro-entrepreneurs.

In most Latin American countries, the informal economy has absorbed increasingly large parts of the work force. ${ }^{23}$ Indeed, in Venezuela most estimates say at least half of the working population labors in the informal sector. Often thought to be the destitute cast-offs of a declining formal sector, studies show that many informal workers make more money and have more autonomy than their peers in the formal sector. ${ }^{24}$ The existence of the informal sector is, of course, controversial. Critics argue that street sellers clutter already congested sidewalks, produce filth, breed crime, and take business away from tax-paying formal businesses. Throughout the I990s, Caracas saw a continual series of political struggles in which municipal governments would alternately work with or combat the informal sector. Municipal authorities have conflicting interests between the desires of the larger society and the attractive possibility of having informal workers as a mobilized source of support gained through legal and illegal concessions. ${ }^{25}$ Informal workers in Venezuela, are organized in varying degrees - from officially licensed cooperatives to local mafias, to groups of ambulatory sellers that look out for each other.

I 999 was a high water mark in these battles in Caracas. On the one hand, it was the first year of the presidency of Hugo Chávez, which, among other effects, brought members of the popular sectors increasingly to see themselves as political subjects capable of exercising power. On the other hand, the mayors of the three main municipalities that make up the

22. John Walton and David Seddon, Free Markets and Food Riots: The Politics of Global Adjustment (Cambridge, 1994).

23. John C. Cross, Informal Politics: Street Vendors and the State in Mexico (Stanford, CA, I998); Roberts "Social Inequalities without Class Cleavages"; Hernando De Soto, The Other Path: The Invisible Revolution in the Third World (New York, I989).

24. Cross, Informal Politics; Cathy A. Rakowski (ed.), Contrapunto: The Informal Sector Debate in Latin America (Albany, NY, 1994).

25. Cross, Informal Politics. 
metropolitan area of Caracas were from opposition parties. During I 999 there were numerous protests in each of Caracas's municipalities. Here, however, I will focus only on one of the main conflicts within the Liberator municipal government. ${ }^{26}$

The mayor of Liberator municipality preceded Chávez in office by a number of years, and had a long, erratic record of alternating attempts to control the informal economy combined with concessions to the same informal workers. At the beginning of I999, the mayor bulldozed the large sprawling La Hoyada market in the middle of downtown Caracas, displacing hundreds of micro-entrepreneurs. The latter agreed to leave on the promise that they would be relocated in a new wing to be added on to an existing market near the centre. After a year passed without seeing their new market they began to pressure the mayor's office. In January I999, they signed an agreement with the mayor for construction of the new wing with the micro-entrepreneurs providing two-thirds of the capital. ${ }^{27}$ Months passed without construction beginning and without any further contact from the mayor's office.

I originally came across the group in March of that year as they protested in front of the City Hall because they had not been given the provisional worksites they had been promised. One of the leaders of that protest warned that if their demands were not met, "we will, because of our need to work and because we are losing our capital, invade a place to work, whether that be a vacant lot or some sidewalk of the downtown area". Indeed, a little over two months later, they invaded a vacant lot across the street from where the previous market had been. They chose this spot because it was the lot where, ten years before, the previous governor had promised he would build a new market. It was definitely one of the most creative protests of the year. Yet the meanings put into play were essentially the same as those of other informal economy protests I covered that year. ${ }^{28}$

From the street it looked like a typical land invasion - in the heart of Caracas: an open field with broken chunks of cement, garbage, and dangerous holes, invaded by hundreds of people. There were dozens of brightly colored umbrellas set up with people sitting underneath, laying on mattresses or pieces of cardboard, leaning against duffle bags stuffed with personal belongings, or sitting on top of plastic cases of bottled beer. Some slept. Others chatted in circles. And others played cards or dominoes while drinking beer. Over the whole vacant lot there were spaces drawn with chalk, including aisles and numbered booths where they were supposedly going to construct their new market. That the participants were members of the lower working classes was evident from their cheap clothing,

26. For a more complete analysis see Lopez Maya et al., Protesta y Cultura en Venezuela.

27. El Nacional Online, ig May 1999, "Invasión en La Hoyada".

28. Lopez Maya et al., Protesta y Cultura en Venezuela. 
decaying teeth, and worn bodies. It reminded me of the bazaars described by Mikhail Bahktin. ${ }^{29}$ It was a carnival atmosphere in which laughter, mockery, and insults melded with serious, critical discussion. In their answers to my questions, respondents' grammatical errors and misused vocabulary produced laughter and mockery from their peers. Some of them pulled the leg of the gringo interviewing them, to the obvious delight of onlookers. But it was clear that these people were conscious of what they were trying to achieve.

Informal micro-entrepreneurs continually confront conceptions of themselves as unsightly reminders of underdevelopment, or as irresponsible impediments to modernity. Indeed, at the beginning of this protest, a major Caracas newspaper ran a picture of the protest on its opinion page with a highly critical and completely uninformed caption. ${ }^{30}$ It said the informal workers' demands reflected "an attitude produced by many years of paternalism - a practice more appropriate in dictatorships than democracies. Because when a government starts to give handouts to adults who should be responsible and self-reliant, it is impeding their liberty even if it is with their consent". ${ }^{\mathrm{I}}$

I carried out twenty interviews, presenting myself as a sociologist doing a study about popular protest. While some of the respondents treated me like as a professor, others treated me as a student, and still others as an international journalist. In light of this, we can assume that in general, respondents presented their opinions in a reflexive manner, trying to convince me, and use me to convince others, of their vision of themselves and their conflict. We should treat this data, therefore, not as reports of fact to be judged for their veracity, nor as a window through which we can view the "true" opinions of respondents, but rather as a rhetorical interaction in which actors put concepts into play. ${ }^{32}$

The analysis I will use here differs from what is usually done under the name "frame analysis", insofar as it does not have to do with a group trying to mobilize participation but rather attempting to change dominant cultural meanings. Participants worked to present their struggle in terms of shared-value orientations of Venezuelan society, ${ }^{33}$ and present more

\footnotetext{
29. Mikhail Bahktin, Rabelais and his World (Bloomington, IN, I984).

30. The editorial caption contradicted the newspaper's own reports regarding the mayor's unfulfilled contract.

31. El Nacional Online, 24 May 1999, "Ver Para Leer: Están Colgados".

32. Kenneth Burke, On Symbols and Society, Joseph R. Gusfield (ed.) (Chicago, IL, I989); James Jasper, The Art of Moral Protest: Culture, Biography, and Creativity in Social Movements (Chicago, IL, I997). David Smilde, "Protagonismo Cultural desde la Pobreza".

33. Habermas responds to the critique that he reifies the distinction between "private" and "common" interests by saying that the discursive struggle of particular groups for public attention must take place in terms of "shared value orientations"; Jurgen Habermas, Between Facts and Norms: Contributions to a Discourse Theory of Law, William Rheg (tr.) (Cambridge, I996).
} 
socially acceptable identities than those usually used to describe them. They tended to present themselves in emotive terms that emphasized their humanity by speaking of their families and the hardships they were facing. ${ }^{34}$ A single mother said the following: "It's been five months already that we've been unemployed, doing nothing. I am a mother. I'm a mother AND a father and I have no way to provide for my child." Another said: "I've been unemployed for five months. I don't know what to do. I'm desperate." A man who was in the shade of the same umbrella told the following story:

I sold children's clothing. Because of these problems, they took away my apartment. I had it mortgaged. I told them [about my situation]. A court took my home away from me and now I'm in the street. My wife is staying in one place, my kids another. Since they demolished the market, I've been in debt.

With reference to the 196I Constitution in effect at that time, participants also attempted to portray their struggle as one having to do with the right to work. "We're trying to apply a little pressure so that they [the authorities] consider our situation, so that they remember that we exist, that we're Venezuelans and therefore have the right to work."

But perhaps most interesting was the way respondents attempted to portray their struggle in ways that contradicted the paternalistic terms in which they were frequently criticized. When I asked him about what they wanted from the mayor's office, one of the participants told me:

Respondent: For starters, we're not asking for handouts.

Smilde: Ah, okay. What are you proposing then? Buying the lots?

Respondent: Buying the lots. The government is going to provide loans for the land and we, on our own accord, are going to construct in an organized manner. We know that this here makes the city ugly. But we are going to be able to do it in an orderly way. The only thing we really need is space, for them to give us the space. We're not asking for handouts, because handouts are never good. But if they could just get us started with the lots, we could pay by installment. No problem. Let us work and bring food to our homes.

The respondents in effect pointed out that they were not asking for charity but planned to pay their part, and wanted to overcome urban disorder rather than contribute to it. Others emphasized that they wanted to become contributing members of formal society:

Respondent I: We're going to become micro-entrepreurs. We're not going to be street vendors anymore. We're going to become micro-entrepreneurs.

Respondent 2: Small businessmen.

34. I should point out that while their reports should not be assumed true, neither should they be assumed false. Seeing responses as "strategic" simply highlights that, even when a respondent is describing real suffering, she is still making a conscious choice to be there at that place and tell that story for rhetorical purposes. 
Respondent I: [we'll have] small businesses legally constituted to contribute to the country. We want to pay taxes and be listed in the Official Gazette, ${ }^{35}$ so they will respect our right to work.

As well, the participants worked to portray their struggle in terms of broader phenomena that would interest others. In their descriptions, the mayor was not only betraying them, he was not fulfilling his obligations to the citizenry in general. "It's not just us. He isn't fulfilling his commitments with anyone. The historical center, freeways, parks, he's abandoned everything. I don't know what this government, this mayor has done. He hasn't done anything." Finally, many put their struggle in terms of broader issues in Venezuelan society. For example, the following respondents described their plight in terms of the discourse of party corruption that had widespread currency in I999:

Respondent I: It's the corruptos that keep our country the way it is.

Respondent 2: Democratic Action [Social Democratic Party] and COPEI [Social

Christian Party].

Respondent I: They're the delinquents.

Respondent 2: They are the corruptos in this country. It's because of them that things are the way they are, millions of people unemployed because of their looting during forty years of democracy.

This discourse of party corruption was used in the Chavez campaign to explain everything from high crime rates to the lack of nontraditional exports. These respondents use it to explain their unemployment and resulting dependence on the informal economy.

If it sounds like I am reading intentionality into respondents' answers, consider the way the following respondents describe what they are doing. "Unfortunately, in Venezuela, in order to be heard, you have to demonstrate. How? By taking to the street or doing something in order to be heard by a mayor or a president, because we are never taken into consideration." Another ended the interview by justifying the protest in the following terms:

If we hadn't come here, you wouldn't have come either because you didn't know that we existed. Now that you know we exist, you can form an opinion about us, that we exist, we have families, we're not asking for handouts. We're simply asking that they respect our right to work. That's it.

In this case study, we see protestors who have created a public in which they could connect with other networks of Venezuelan society in order to influence them. Their struggle simply was not on the public docket and as a result the municipal government could completely ignore their demands. publicly announced. 
By going forth with their "invasion" they were able to bring the broken promise to public light, portray their demands in nonpaternalist terms, present their situation of need in human and constitutional terms, and portray their adversary as a general social problem. It was one of the most successful protests of the year. The mayor had to respond publicly and, after unsuccessfully trying to pass the problem off onto the federal government, presented a project to construct $82 \mathrm{I}$ new booths in the San Martin Market. Eighteen days after invading, the participants signed a new agreement with the mayor and abandoned the field. ${ }^{36}$ The problem between the members of the informal economy and the municipal government continued for the rest of the year and up until the mayor was voted out of office in 2000 in favor of chavista, Fredy Bernal. After a few attempts to control the informal economy Bernal completely threw in the towel and permitted street sellers to occupy public spaces throughout the city.

\section{PLAZA SERVICES}

As is the case in most Latin American countries, one of the most vibrant forms of civil society in contemporary Venezuela is popular religion - in particular, Pentecostal Christianity. In the I970s and I980s, Pentecostal growth in Venezuela lagged behind that experienced by other Latin American countries. But it accelerated considerably during the downward spiral of the I990s, and non-Catholic Christians currently constitute around 5 per cent of Venezuela's population. Despite stereotypes of Pentecostalism as a religion of the dispossessed, Pentecostals closely reflect the class structure of the larger society. ${ }^{37}$ However, since most forms of civil society such as neighborhood associations, environmental groups, and women's rights activists have been successful mainly with the middle and upper-middle classes, Pentecostals stand out for being able to mobilize the lower classes. The Pentecostal theology of a supernatural battle between good and evil that impinges on humans depending on their behavior, presents individuals with a way to get a cognitive fix on the processes that are affecting their lives, and provides the energy necessary to overcome the classic obstacles to associational mobilization among the popular sectors.

Virtually every plaza in Caracas has a Pentecostal service or pastor preaching at some point during the day. These events range from a selfappointed individual preaching to a captive audience at a bus stop, to wellorganized initiatives, with sound equipment and municipal permits, that

36. El Nacional Online, 5 June 1999, "Buhoneros Desocuparon Terrenos de La Hoyada". 37. David Smilde, "Contradiction without Paradox: Evangelical Political Culture in the 1998 Venezuelan Elections”, Latin American Politics and Society, 46 (2004), pp. 75 -102. 
dominate a plaza for several hours daily. One of the oldest examples of the latter is the service that takes place every day at noon in the Plaza El Venezolano in the heart of downtown Caracas. A block from the Plaza Bolivar, and two blocks from the National Assembly, the Plaza El Venezolano is swarming with ice-cream vendors, shoe-shine men, people on work breaks, and parents with small children virtually all day long. The plaza has four fountains that haven't functioned in years, poured cement benches, and low cement planters on which people sit. On the whole north edge of the plaza there are steps going up to the street, which create an amphitheater for the noontime services.

A service begins to build around noon, with informal singing by those Pentecostals who arrive early. At ten or fifteen minutes past the hour, the person who is directing the event introduces the first preacher, who begins with a Bible reading and then preaches for a half hour or so. There is generally a dominant theme, but the preaching is ad lib, using no notes, and any number of topics might be touched upon. Towards the end, the sermon works into an informal, but highly structured, altar call. First, the pastor will query the audience with a question likely to receive a positive response: "Raise your hand if you believe in Jesus". The knowing regulars leave the visitors to respond. After the preacher gets those in attendance to raise their hands, he then announces that he would like them to come down so that he can pray for them. He then prays over the ten to twenty people who have complied and congregated around him. Afterwards, someone from the church with a notepad takes down their names and gives them a Bible tract. Interestingly, since the names are simply for prayer, they do not take down a phone number or address or anything else to follow up.

I have seen these plaza services, depending on the day, the weather, and the skills of the preacher, draw anywhere between 30 and 200 onlookers. There are three basic strata of attendees. Those standing behind or close to those leading the service are Pentecostal regulars who may have a hand in organizing the plaza services. They sit behind, giving claps and hallelujahs to points they agree with, and play instruments - bongos, guitar, drums, maracas - during the singing. They also constitute the pool of fill-in preachers on those occasions that a scheduled preacher does not show up. Then there are those who are sitting on the steps in front of the preacher. These are usually Pentecostals from different congregations, and other people who are interested to the point that they want to sit down to watch but do not have a hand in organizing the plaza services. Behind those sitting on the steps stand curious onlookers.

The Pentecostals who frequent the plaza service are often stereotyped as people with "nothing better to do". But like the men on Tally's Corner, ${ }^{38}$ they are often those who work after hours in security or cleaning jobs, are

38. Eliott Liebow, Tally's Corner: A Study of Negro Streetcorner Men (Boston, MA, I967). 
between stints of marginal employment, or work for themselves on their own schedule. Others work downtown and come on their lunch breaks. One of the plaza preachers, Ramiro, for example, works independently as a remodeling contractor. When he is between contracts he attends the plaza service everyday. When he is working, he makes a strong effort to take a long lunch on Thursdays - his day to preach. The mission of the plaza services is, in principle, ecumenical. There are no prohibitions of people from any given denomination. But the litmus test of who can preach has to do with fidelity to basic Evangelical doctrine.

In contrast to popular stereotypes, preachers are not motivated by the offerings they collect, but rather by strong commitments to preaching. The pittance they usually round up goes to purchase Bible tracts to pass out or is saved for equipment upgrades. One can see in them a desire and impulse to make meaning. Once when the municipal authorities completely shut down the plaza services for several weeks for lack of proper permits, Ramiro expressed his anxiety at the news they had been closed down. "A month?! I can't do it! I have to preach. I'll go to La Hoyada (another plaza). I preach on Thursdays and Sundays and even that's not enough." Another longtime preacher added, as if to explain: "The Lord puts the word in you and it has to come out."

Most plaza preaching focuses on "true" versus "false" Christianity or addresses problems with primary social relationships or personal adjustment by enjoining self-examination. Narratives are told of families that fall apart because of substance abuse, important executives who self-destruct because they forget about God, and children growing up without moral guidance. Nevertheless, larger society frequently comes into focus. Venezuelans have for centuries had a sort of antinationalist discourse, whereby they compare their country in disfavorable terms to other countries, ${ }^{39}$ a discourse that has only accentuated with the "crisis" of the past twenty years. Pentecostalism latches onto this discourse quite readily. $4^{\circ}$

Venezuela's problems are explained as the results of or even punishment for a country that has turned its back on God and comparisons are made to more "Godly" nations like the US and Canada. Frequently, prayers are raised up asking God to intervene in Venezuela. "We're praying for Venezuela. For God to take action", prayed one preacher. "The Bible says that 'if the just ask, God provides'. So we are asking God to take action with Venezuela." Pentecostal meanings are frequently used in a more concrete sense, as well, to explain the corruption scandals that pepper the

39. Martiza Montero, Ideología, alineación, e identidad nacional (Caracas, 1984); David Smilde, "Protagonismo Cultural desde la Pobreza".

40. Idem, "El Clamor por Venezuela: Latin American Evangelicalism as a Collective Action Frame”, in Christian Smith and Joshua Prokopy (eds), Latin American Religion in Motion (New York, 1999). 
daily news. Ramiro, for example, preached "There are terrible scandals in this country. And it's all right here [holding up the Bible].” In I996, plaza preachers addressed the acute inflation that followed a currency devaluation that dramatically affected the lower classes. One preacher taught "Venezuela has oil, vast resources under the earth. But do you know which currency had devalued more than any other in the world? The Bolivar [Venezuela's national currency]. Idolatry brings ruin.” Another provided both an explanation and a reason for confidence:

The housewife goes to the supermarket [...] and she sees that [powdered] milk has gone up to Bs 3,000 [approximately \$6US] a kilo and she gets scared because she doesn't know what is going to happen. Do you know why milk keeps going up? Because the Word is being fulfilled [raises Bible]. I am one of those Pentecostals that, although milk goes up, and meat goes up, butter goes up, I am happy every day. It's not that we don't have problems. We do. But we don't resolve them. Christ takes care of them.

The most common passage used to address the Venezuelan crisis is Matthew 24.I-35 regarding the "signs of Christ's return". One plaza preacher used a grease pencil and board in his service, to draw a diagram listing the symptoms of Christ's return: "Many will deceive in His name. Wars. Rumors of wars. Nations will rise up against nations. Plagues. Hunger. Earthquakes." Systematically he went through each symptom and related it to recent events in Venezuelan or world society.

As is the case in many countries in the developing world, public discussion of collective life in Venezuela traditionally follows a developmentalist discourse that sees the state as the primary mover of development. ${ }^{4}$ Plaza preachers crosscut this discourse by portraying "true" Christianity as an alternative to politics and the state. "Politics has not been able to do anything for my country. Every day it gets worse and worse. But Christ fulfills his promises", said one preacher. Another followed the testimony of an exconvict who had converted to Pentecostalism, by taking the microphone and pointing to him:

Religion [Catholicism] wasn't able to change him. Politics wasn't able to change him. The State wasn't able to change him. The police weren't able to change him. The psychologist wasn't able to change him. Prison wasn't able to change him. The only thing that could change him was the power of God.

The organizers of these plaza services explicitly seek a public forum to present their ideas and thereby extend their networks and the influence of their discourse. One preacher emphasized this in my interview with him:

This is the historic center [of the city]. All types of people pass through here, (Chicago, IL, I997); James Ferguson, The Anti-Politics Machine: "Development", Depoliticization, and Bureaucratic Power in Lesotho (Minneapolis, MN, 1994). 
from all social classes. The upper classes. Politicians. People from the middle class, lower-middle class, and the lower class too, all pass by here. In other words, it's a strategic point and God has a message for all of these people.

One of the founding members emphasized that the time of their service allows them to catch people in transition. "That's the time when people come to eat and rest. The fish are schooled. So you take the opportunity to throw the net, to throw the Gospel at them."

Compared to the case study reviewed in the previous section, it is difficult to know how much of an impact these services have on the thousands of people who walk past or stop for a few minutes or hours to listen to the services. What can be said is that they are consistent with, and perhaps reinforce the tendency among new social movements to look for alternative, often morally charged meaning systems with which to talk about issues of collective life..$^{2}$ One palpable example is the rhetoric of current president, Hugo Chávez. Chávez, who was frequently visited by Pentecostal preachers during his two years in jail after the 1992 coup attempt, has repeatedly reached out to Pentecostals, and frequently uses Pentecostal imagery in his public speeches. ${ }^{43}$ This imagery is one of the foundations of the divisive character of his discourse.

At a lower level, these public plaza services are an important means of recruiting converts. Compared to one-on-one evangelization, plaza services are non-threatening and permit a low-intensity engagement for those who are interested in "trying on" the Evangelical belief system. ${ }^{4}$ There are other impacts. The plaza services are not just about preaching. Before and after the services or during and towards the periphery, the plaza is a place for Pentecostals to visit, exchange information relevant to economic opportunities, or meet up for an afternoon activity. In a context in which there is no functioning mail system and telephone communications can be difficult, such a recognized meeting place plays a vital function. There are other ways in which networks are bridged and new relationships are formed between Pentecostals from different churches and between Pentecostals and non-Pentecostals. During the service a few Pentecostals work the crowd passing out Bible tracts with evangelistic messages on them. Others hand them to passers-by.

The peripheries of the plaza service also serve as sites for counseling for both Pentecostals and non-Pentecostals. A non-Pentecostal who wanted to commit suicide because of his dependence on prescription drugs, a

42. David Smilde, "Los Evangélicos y la Polarización: la moralización de la política y la politización de la religión”, Revista Venezolana de Ciencias Economicas y Sociales, I0:2 (MayAugust 2004), pp. I63-179; idem, "El Clamor por Venezuela".

43. Idem, "Contradiction without Paradox"; idem, "Los Evangélicos y la Polarización".

44. Idem, "Works of the Flesh, Fruit of the Spirit': Religious Action Frames and Meaning Networks in Venezuelan Evangelicalism" (Ph.D., Department of Sociology, University of Chicago, 2000). 
Pentecostal whose wife has left him with their children, and a young nonPentecostal who feared he would lose his job, were some of the cases I witnessed during my participant observation. In all such cases the problem is given a Pentecostal interpretation as an earthly manifestation of the struggle between God and the Devil, and a prayer is raised asking God for help. If the person is non-Pentecostal, he or she is usually counseled to regularly attend a Pentecostal church. There are also occasionally transnational contacts made at the plaza services. The plaza services are frequently on the schedule of short-mission trips from North America that present dramas or puppet shows with translations depicting Biblical stories. Venezuelan and North American Pentecostals often establish relationships as a result of such collaboration.

\section{DISCUSSION}

Popular participation in the public sphere in Latin America today presents a paradox. On the one hand, the political representation of popular classes is clearly one of the great casualties of the neoliberal era in Latin America. The decline of the labor movement as well as class-based parties has left masses of people without institutionalized political representation. ${ }^{45}$ On the other hand, popular participation in the public sphere has become increasingly important. From the zapatistas in Chiapas, who have now held the Mexican army at bay for a decade, to the indigenous groups of Ecuador, who have brought down two presidents and helped bring another to power, to the Bolivarian movement of Venezuela that brought a failed coup leader to the presidency and brought him back from exile when he was overthrown, popular participation in the public sphere has demonstrated its power. The extra-institutional, ephemeral and episodic character of these forms of popular politics have spawned a number of attempts at conceptualization. Walton and Seddon ${ }^{46}$ speak of "food riots" that respond to neoliberal "shock measures". Manuel Castells sees "communal resistance" developing among those excluded from the global "network society". ${ }^{47}$ Michael Hardt and Antonio Negri see the "multitude" as a decentered, episodic reaction to "Empire" - the globalized structure of biopower..$^{8}$

Unfortunately, while each of these concepts captures the ephemeral and episodic nature of popular participation in the public sphere, they miss the planned and reasoned forms of agency that actual fieldwork reveals. The term "popular intellectual" is a useful corrective here since it focuses on

45. Portes et al., "Latin American Class Structures"; Roberts, "Social Inequalities without Class Cleavages".

46. Walton, Free Markets and Food Riots.

47. Manuel Castells, The Power of Identity: Economy, Society and Culture (Cambridge, 1997).

48. Michael Hardt and Antonio Negri, Empire (Cambridge, 2000). 
discourses and symbols that are consciously created and endure beyond the episodes in which they are put into play. With the term "popular publics" I try to preserve this emphasis, but also change the unit of analysis from individual or collective actors, to relational contexts. Actors exist. But it is the relational context that endures beyond the shifting composition of the actors involved. And it is the extended networks and expanded discourses that endure beyond the relational context of a given public.

In the two cases examined here we see relational contexts in which nonelite sectors of Venezuelan society participate in reflecting on and discussing collective life and alternative futures. Through these publics they seek to extend their networks and the influence of their discourses, and thereby gain the social influence they lack in institutionalized politics. In the first case, we see informal workers seeking to modify dominant portrayals of themselves and their struggle. In the second case, we see Pentecostal plaza services in which preachers use an alternative rationality to analyze and critique Venezuelan society. Nevertheless, they quite rationally plan the location and the time of their preaching to maximize their effect. This analysis does not intend to romanticize popular publics, ${ }^{49}$ nor advocate the positions they express. ${ }^{50}$ The goal is rather to improve our understanding of the public participation of popular sectors in developing-world contexts.

49. While in my portrayal popular publics are not as reactive and futile as Castells's communal resistance, neither do they merit Hardt and Negri's "millenarian optimism"; see Gopal Balakrishnan, "Review of Hardt and Negri's Empire", New Left Review, 5 (2000), pp. I43148. Whether they improve social conditions or concrete lives in any given case is an open question. Regarding Venezuela, for example, Levine writes that enduring power does not necessarily follow from momentary empowerment. Therefore, civil mobilization and protest alone is "unlikely to provide coherence and direction for a complex and conflict-ridden society" like Venezuela; see Levine, "Democracy in Venezuela", p. 26r.

50. Popular movements have no Archimedean standpoint that ensures truth, nor any teleology that guarantees they work for justice. Ku Klux Klan meetings and skinhead internet chat rooms are "popular publics" too. For an extended discussion of this point, see Luis Pasara, La Otra Cara de la Luna: Nuevos Actores Sociales en el Perú (Buenos Aires, 199i). 